sciendo Порівняльна професійна педагогіка 8(2)/2018

DOI: $10.2478 /$ rpp-2018-0029

Foreign Languages Lecturer, ALLA SHTEPURA

Mykola Hohol Nizhyn State University, Ukraine Address: 2 Hrafska Street, Nizhyn, 16600, Ukraine

E-mail: allonka2870@ukr.net

\title{
THE IMPACT OF DIGITAL TECHNOLOGY ON DIGITAL NATIVES' LEARNING: AMERICAN OUTLOOK
}

\begin{abstract}
Constant development of information and digital technologies changes the learning process and the specifics of social relations between the student and the teacher. The use of new means of communication makes an important contribution to the development of skills in using technology, intensive self-study and social interaction. A new generation of students uses digital technology daily. The article shows the impact of digital technology on a new generation of students, digital natives, and their learning. It has been defined that a lot of scientists have been studying the impact of information technology on digital generation, advantages and disadvantages of digital technologies. It has been stated that some scientists (M. Spitzer, J. Bauer) point out that there isn't any indication that digital media accelerate or deepen the brain development process and don't have any positive effect on its development. Today's students cannot do without IT technologies - computers, mobile phones, the Internet, applications: video and music, text messaging. Nevertheless, Nicolas Carr notices that texting and instant messaging may weaken human creativity. It is also mentioned that multitasking leads to more superficial learning and less efficient processing of information. Generation of digital natives creates their own social network in their virtual world (a new culture of communication, a new language, new abbreviations which are used for writing messages). As for forms and methods of learning, it is extremely difficult for them to attend lessons and they prefer to be active and to work autonomously. They use the Internet as the main alternative to the traditional literary sources. Learning should be interactive, creative and autonomous for them. The organization of the educational process for digital natives is not an easy task, because they require varied and very stimulating learning environment. Thus, it has been proved that new digital technologies and the Internet can bring not only damage and danger, but also give huge benefits. These benefits should be taken into consideration and appropriate educational programs should be developed and introduced into digital natives' learning.
\end{abstract}

Keywords: generation, digital natives, digital immigrants, impact, Internet, educational technology, learning, teaching.

\section{INTRODUCTION}

A large-scale development of digital technology completely changes the learning process, changes the specificity of the social relation and information exchange in the youth's life that has access to them and knows how to use them. The use of new means of communication makes an important contribution to the development of skills in the use of technology and social interaction. In addition, electronic means of communication provide an opportunity for intensive self-study and their topics are determined by the interests of a particular user. The benefits of digital technology are not constrained by any limits and not limited to optimization of the learning process but encompass the development of man's 
creativity, entrepreneurial skills and active life position. Teenagers and young learners use such technologies as audio, video recordings and different games for self-expression. The advantages of far-reaching digital technologies extend beyond learning in order to promote creativity, entrepreneurship and activism of students (Palfrey, Gasser, \& Maclay, 2011).

THE AIM OF THE STUDY

The challenge which lies before us is the development and implementation of educational interactive opportunities for young people. They allow them not to lose opportunities in learning that appear in their life due to digital technologies and also to overcome arising difficulties in it. Therefore, it is necessary for students to become critical consumers of information, be informationally literate, not only to use information and information technology effectively and adapt themselves to the constantly changing conditions, but also be able to think critically about the information industry and the information society in general. The aim of the study is to show the impact of digital technologies on a new generation of students.

\section{THEORETICAL FRAMEWORK AND RESEARCH METHODS}

Modern educational technologies are caused by three main technical factors computer technology, information networks and multimedia. They contribute to human development. Computer technology helps to individualize learning, provide feedback of the students, release students from routine work. But we should understand how this computer technology affects the current generation of students in general.

It is important to note that a lot of psychologists and teaching methodologists all around the world pay close attention to the problem of digital technologies and its influence on a new generation of students: S. Bennett (2010), M. Best (2013), B. Dalgarno (2010), R. Eynon (2010), E. J. Helsper (2010), Kian-Sam Hong (2014), T. Judd (2010), G. Kennedy (2010), K. Maton (2010), M. Musgrove (2008), M. Prensky (2001), J. Waycott (2010) et al.

The term "generation" was also defined according to different ideologies and technological evolution over time. Different kinds of generations have been identified and investigated: Traditionalists (Silent, Veterans, Matures), Baby Boomers, Generation X (Gen X, Xers), Generation Y (Gen Y, Millenial, Echo Boomers), Gen Z (iGen), Gen Alpha (The Generations, 2018).

The topic of our research is Generation Z (Gen Z), so called "Digital Natives" (as the current students belong to this category), and the impact of digital technologies on it.

\section{RESULTS}

An American writer and popularizer of technology training and education, M. Prensky (2001) determines "digital native" term in his article "Digital Natives, Digital Immigrants". He uses this term to a group of students of a young generation ("native speakers") who easily use digital technologies such as computers, videos and video games, different websites and applications, digital media. The meaning of the concept "digital native" is close to the concept of Generation $\mathrm{Z}$ (a significant aspect of this generation is its widespread usage of the Internet from a young age). A "digital man" is considered as the native of the "digital age". People who were born before the start of the "digital age" M. Prensky called "digital immigrants" (Digital native, 2018).

A lot of scientists have been studying the impact of information technology on digital generation. Gary Small and Gigi Vorgan in their book "iBrain: Surviving the Technological Alteration of the Modern Mind" (Small, \& Vorgan, 2008) reveal the remarkable brain evolution by the present technology. They separate the digital natives - 
sciendo Порівняльна професійна педагогіка 8(2)/2018

Comparative Professional Pedagogy 8(2)/2018

those born in the age of computers - from the digital immigrants, who uncover computer technology at the age of adults.

In the opinion of the neurobiologist M. Spitzer, the use of digital media by young people can negatively affect the process of their education, creating difficulties in the development of sensory-motor sensations, which leads to serious changes and restrictions in social contacts (Chorab, 2016). Deep mental work, which is a prerequisite for the learning process, has been replaced by the digital surfing and viewing and lost profound mental processes. Neurobiologists Manfred Spitzer and Joachim Bauer (Chorab, 2016) point out in their researches that they have not received any indication that digital media accelerate or deepen the brain development process and don't have any positive effect on its development.

Generation of digital natives, today's students and pupils, has never known a world without IT technologies: computers, mobile phones, the Internet, applications (video and music, text messaging). The Internet mobility has always been available for them. Networked media and communication make up the basement of their lives. In order to find some information or consult a dictionary many natives never borrow books from the library, or look something up in a traditional encyclopedia; they use Google, Yahoo and other online search engine. They are used to the immediacy of hypertext, downloaded music, mobile phones, a library on their laptops and computers, and being connected anytime and anywhere. They've been networked most or all of their lives. It is natural for them to be always connected and at the same time they have always constant conversations in their social networks by means of a text and instant messaging. American scientist Nicolas Carr notices that texting and instant messaging may weaken human creativity (Carr, 2010).

The phenomenon of multitasking of multimedia has appeared with the advent of digital media. Cognitive skills required to perform several tasks simultaneously are weaker in the case of frequent task changes. Multitasking leads to more superficial learning and less efficient processing of information. Nicolas Carr (Carr, 2010) warns that multitasking is not an efficient way to do things. We can note that in contrast to multitasking which is not difficult for them, generation of digital natives complains that books make them feel isolated while they want to stay in touch with their friends online (Shtepura, 2016). Young people create their own social network in their virtual world, they are creators of a new culture of communication, form a new language, with new abbreviations which are used for writing SMS-messages in particular (the principle of maximum efficiency), create new rules of conduct.

On the one hand, technological progress has brought a lot of new ways of learning in the classroom and at home. There are various online courses for everyone: pupils, students, adults. Search engines such as Yahoo and Google provide enormous resources for research on any topic. Computer programs such as Kurzweil, Leapfrog, Fast Forward and Draft: Builders are designed to help young learners to learn to read and write earlier and to develop their hand-eye coordination at a young age. Scientists consider that it is very boring and extremely difficult for digital natives' students to have traditional lectures (making notes, getting information). The traditional approach to teaching reduces education to a transfer of information.

On the other hand, before the Industrial Revolution, when books were not yet mass merchandise, the method of a lecture was the only way to transmit information from generation to generation. The traditional method of lecture ignores the fact that many people study in different ways. Sometimes we observe the method of lecture as a process where notes of the lecture are transmitted to students' notebooks without passing through their brains. As the matter of fact, we can observe such learning process in the classroom. 
Most technologies in education are no more than a new effective implementation of the old approaches, and therefore the technology is not a magic bullet (Traditional lectures don't work, 2009). Digital natives use the Internet as the main alternative to the traditional literary sources. In this context, they are faced with the problems of the origin, the accuracy and reliability of the found material, which are mainly superfluous in the framework of the usual forms of academic publishing. The quality of information contained in books, journals and other types of printed products was provided earlier due to various factors and reputable publishers, recognized and academically distinguished authors, lecturers. However, as for the Internet resources, we can say that the mechanisms of such quality maintenance do not work. The user is forced to assess them critically.

What concerns digital students, it is extremely difficult for them to attend lessons, when they are unable to be active and work autonomously. It is obvious that when they work in the Internet, they are accustomed to the smooth transition from the role of recipient to the role of creator. Learning is best when it is interactive. Students need to interact with the material outside the classroom, reading textbooks, re-reading notes, re-organizing lecture notes and incorporating them with the book notes, doing problem sets and additional practice problems. Furthermore, interactive technologies allow individuals to be selfreliant, as well as collaborative, as they are active participants in the learning process which depends on their further actions to continue and involve other participants in it.

Moreover, many young people have their blogs where they can express their own thoughts, read different articles and comment on them. Generation of digital natives knows how to use the space of freedom which is opened before them due to the Internet. Students, who have been educated in the world of new technologies, perform some tasks better and more efficiently than previous generations. For example, they can seek faster for the necessary information from the Internet. This high efficiency is possible because the brain of digital natives has a high ability to concentrate, needed to analyze and search information. The speed of information processing is the case of quick work of their brains. We should keep in mind that the brain of digital natives encodes information differently than the brains of digital immigrants. There is a possibility of parallel information processing, which allows them to perform multiple actions simultaneously. Digital natives are guided by the principle of maximum efficiency and pragmatism in their actions. They enjoy working with materials that contain many graphic elements such as drawings, photographs, diagrams, graphs, etc. and have their persistent tendency to multitask (Abram, \& Luther, 2004). Young people prefer tasks which require creativity and independence, as well as various forms of activity and provide a transition from the orderly and linear processing of information, with interest working on tasks that require independent search of information. The organization of the educational process for digital natives is not an easy task, because they require varied and very stimulating learning environment.

Undoubtedly, new technologies motivate and engage young people in learning process. However, its gain as an advantage for learning is tangible only if the activity is effectively aimed at what and how to learn (Higgins, Xiao, \& Katsipataki, 2012).

What is more, teaching and learning in an ODL (open distant learning) environment gives open access to different learners with no limitation on age, social and marital status. Maybe it is a good way to involve them in the process of education because it also gives a good opportunity for Gen $Z$ to find themselves in their native environment. If teachers and parents accept that today's students are different, they can start to make 
sciendo Порівняльна професійна педагогіка 8(2)/2018

Comparative Professional Pedagogy 8(2)/2018

positive changes to continue educating digital natives in the way appropriate to their nature. If teachers are willing to change, they will find how to connect with their students more easily. Nowadays, there are many ways of using digital tools and technologies of distant learning, which can help students improve their skills in different branches. It is the educator's job to steer their students in the right direction and help them get the most from these relatively new kinds of tools.

\section{CONCLUSIONS}

In high schools we should use the potential that comes from the collaboration of students and teachers in training process. Digital technology and the Internet are best used not only for finding information, but also for working on team projects. Digital tools are the best way to help students in that work. The need of the day is the creation of a new methodology of teaching, which takes into consideration all the changes in the world and in the minds of students and allows using creative potential of new technologies to the full, without abandoning other forms of acquiring knowledge.

Thus, the origins of the Internet and many other electronic and digital resources bring up a number of new issues to higher education. These technologies offer new wide opportunities to improve learning and teaching for the current generation of students, generation of digital natives. New digital technologies and the Internet can bring not only damage and danger, but also give huge benefits, but only when users are able to take up the role of active creators, not passive recipients. Superficial and excessive unreasonable use of digital technology resources lead to incoherent knowledge structure. Brain research shows that the brain is changing with the use of digital technologies; the daily use of digital media cannot be left without any impact. We should remember about the results of this impact on current students and help them not to lose motivation to study. Furthermore, digital media could be useful for society if appropriate educational programs were developed and introduced into up-to-date educational establishments.

Thus, taking the above mentioned into account, we consider it to be necessary to carry out further research concerning development and implementation of appropriate educational programs aimed at digital media introduction in schools.

\section{REFERENCES}

1. Abram, S., \& Luther, J. (2004). Born with the chip: the next generation will profoundly impact both library service and the culture within the profession. Library Journal, $129(8), 34-37$.

2. Carr, N. (2010). The shallows. What the Internet is doing to our brains. New York; London: W. W. Norton \& Company.

3. Digital native. (2018). Retrieved from https://en.wikipedia.org/wiki/Digital native.

4. Higgins, S., Xiao, Z., \& Katsipataki, M. (2012). The impact of digital technology on learning: a summary for the education endowment foundation. Full Report. Durham University: Education Endowment Foundation.

5. Chorab, G. (2016). The brain to new technologies: the risks and losses. General and Professional Education, 1, 9-15.

6. Palfrey, J., Gasser, U., \& Maclay, C. (2011). Digital natives and the three divides to bridge. The state of the world's children. New York, NY: United Nations Children's Fund.

7. Prensky, M. (2001). Digital natives digital immigrants. NCB University Press, 9 (5), $1-6$. 
sciendo Порівняльна професійна педагогіка 8(2)/2018 Comparative Professional Pedagogy 8(2)/2018

8. Small, G., \& Vorgan, G. (2008). iBrain: surviving the technological alteration of the modern mind. New York, NY: Harper Collins e-books.

9. Shtepura, A. P. (2016). Chy potribni pidruchnyky "Tsyfrovym aboryhenam"? Materialy V Mizhnarodnoi naukovo-praktychnoi konferentsii "Innovatsii v osviti: suchasni pidkhody do profesiinoho rozvytku vchyteliv inozemnykh mov". Nizhyn: Vydavets PP Lysenko M. M.

10. The Generations (2018). Which generation are you? Retrieved from https://www. careerplanner.com/Career-Articles/Generations.cfm.

11. Traditional lectures don't work. (2009). Retrieved from http://biocurious.com/ 2009/01/02/traditional-lectures-dont-work. 